\title{
Pengaruh Informasi Teknologi Terhadap Hubungan Antara Strategi dan Kinerja Perusahaan
}

Cahyo Adityo Irawan

s130118033@student.ubaya.ac.id

Melalui teknologi, perusahaan melakukan strategi untuk mendapatkan keuntungan melalui investasi dan diharapkan dapat membantu kinerja perusahaan. Dengan teknologi, perusahaan dapat menjangkau jaringan yang lebih luas dari banyak industri yang dapat membawa perubahan dalam kinerjanya menjadi lebih baik lagi dari sebelumnya. Peningkatan ketersediaan jaringan dan teknologi dapat membantu perusahaan untuk berinvestasi dalam teknologi informasi. Jadi, perubahan dan kemajuan teknologi dapat mendorong perusahaan untuk menciptakan peluang baru. Akses dari teknologi informasi membuat perusahaan lebih proaktif untuk mengidentifikasi dan mencapai peluang. Teknologi membantu perusahaan untuk mengembangkan kemampuan mereka dalam jaringan, pelayanan customer dan informasi yang cepat. Bisa dikatakan teknologi informasi yang berkembang pesat memungkinkan persuahaan menciptakan inovasi yang baru. Perusahaan juga dapat memperoleh informasi kebutuhan dan keinginan pelanggan dengan cepat yang dapat mengingatkan tentang persaingan pasar yang baru dan juga perkembangan teknologi yang terjadi. Strategi yang diharapkan berpengaruh pada kinerja perusahaan membutuhkan faktor dari teknologi. Jadi di bawah teknologi informasi yang tinggi, strategi berdampak positif pada kinerja perusahaan. Sebaliknya di bawah teknologi informasi yang rendah, strategi perusahaan berdampak negatif pada kinerja perusahaan. 